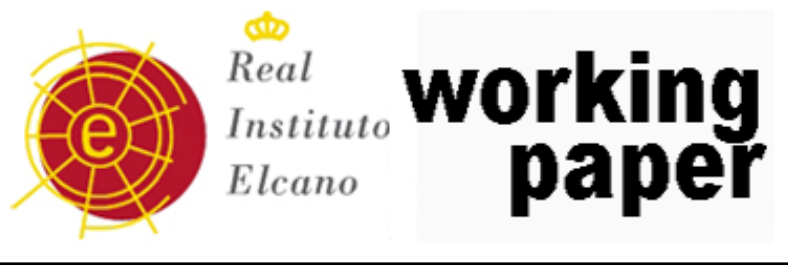

\title{
Dollar Dominance, Euro Aspirations: Recipe for Discord? (WP)
}

\author{
Benjamin J. Cohen
}

Area: International Economy and Trade

Working Paper 29/2009

28/5/2009

Elcano Royal Institute

Madrid - Spain

www.realinstitutoelcano.org 


\title{
(Q)
}

\section{Dollar Dominance, Euro Aspirations: Recipe for Discord?}

\author{
Benjamin J. Cohen
}

\section{Summary ${ }^{1}$}

After nearly a century of dominance of the international monetary system, has the US dollar finally met its match in the euro? When Europe's Economic and Monetary Union (EMU) came into existence in 1999, many observers predicted that the euro would soon join America's greenback at the peak of global finance. Achievements, however, have fallen short of aspirations. After an initial spurt of enthusiasm, international use of the euro now actually appears to be levelling off, even stalling, and so far seems confined largely to a limited range of market sectors and regions. The euro has successfully attained a place second only to the greenback, but it remains, and is likely to remain, a quite distant second without a determined effort by EMU authorities to promote their money's global role. The temptation will surely be great. In practical terms, it is difficult to imagine that EMU authorities will refrain entirely from trying to promote a greater role for the euro. But that, in turn, could be a recipe for discord with the US, which has never made any secret of its commitment to preserving the greenback's world-wide dominance. A struggle for monetary leadership could become a source of sustained tensions in US-European relations. Fortunately, however, there seems relatively little risk of a destabilising escalation into outright geopolitical conflict.

\section{Dollar Dominance, Euro Aspirations}

After nearly a century of dominance of the international monetary system, has the US dollar finally met its match in the euro? For many observers, the prospect has long been self-evident. Even before Europe's Economic and Monetary Union (EMU) came into existence in 1999, prominent economists such as George Alogoskoufis (later to become Finance Minister of Greece) and Richard Portes were predicting that 'the fundamentals point towards a potentially large shift in favour of the euro' (Alogoskoufis \& Portes, 1997, p. 63). The joint currency of the EU could legitimately aspire to join America's greenback

\footnotetext{
* University of California Santa Barbara.

${ }^{1}$ This paper is an edited version of a longer article to appear in a forthcoming issue of the Journal of Common Market Studies.
} 


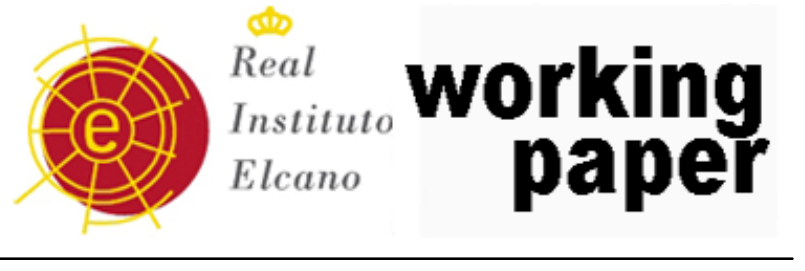

at the peak of global finance. Over the decade since the euro's debut, Europe has seemed well on its way to becoming a new monetary power. The fate of the dollar appeared to be sealed following the collapse of America's housing market in mid-2007, which triggered the greatest crisis in US financial markets since the Great Depression.

Appearances, however, can be misleading. In fact, the euro's achievements as an international currency have fallen disappointingly short of aspirations. Admittedly, the money has done well in exchange-rate terms. Market value soared from a low of around US\$0.83 in mid-2002 to as high as US\$1.60 in mid-2008, before dropping back more recently. But exchange rates are at best an imperfect indicator of a currency's global standing. The real issue is not price but use: the extent to which the euro is being adopted by actors outside the EMU for the standard functions of a medium of exchange, unit of account or store of value. When it comes to international use, the shift in favour of Europe's money has, for the most part, been anything but large. After an initial spurt of enthusiasm, interest in the euro now actually appears to have levelled off, even stalled, and so far seems confined largely to a limited range of markets and regions. Not even the present troubles of the US financial sector, which have required massive government interventions and in some cases de facto nationalisation, have sufficed to tip preferences away from the dollar. If anything, the crisis has ironically served to reinforce the greenback's global dominance.

In short, power configurations in currency relations have changed much less than expected. The euro has successfully attained a rank second only to the greenback, but it remains, and is likely to remain, a quite distant second. Without a determined effort by EMU authorities to promote their money's role, any challenge to the dollar will remain modest at best.

Would Europe dare to mount a direct challenge? No one really knows, but the temptation will surely be great -particularly at a time when America's financial stresses would seem to have heightened the greenback's vulnerability-. European policy makers understand the material benefits that would result from wider use of their currency. These include a sizable gain of seigniorage, which would accrue from increased foreign holdings of euros or euro-denominated assets, as well as a higher degree of macroeconomic flexibility that would derive from the ability to finance external deficits with Europe's own money. In practical terms, it is difficult to imagine that EMU authorities will refrain entirely from trying to encourage a greater role for the euro. But that, in turn, could become a recipe for discord with the US, which has never made any secret of its commitment to preserving the 


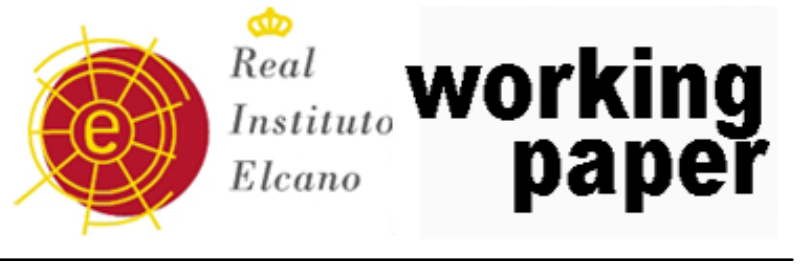

greenback's worldwide dominance. An overt struggle for monetary leadership could become a source of sustained tensions in US-European relations.

The purpose of this essay is two-fold: first, to review the euro's global performance to date; and, secondly, to explore the implications of a possible leadership struggle for monetary dominance in years to come. A brief look at available evidence confirms the euro's limited achievements in most international uses, falling far short of enthusiasts' aspirations. A glimpse at future prospects for the dollar-euro rivalry confirms the possibility of US-European tensions but, happily, suggests little risk of a destabilising escalation into outright geopolitical conflict.

\section{The Broad Picture}

Early forecasts for the euro's future were strikingly optimistic. A decade ago the US economist Fred Bergsten (1997) proclaimed emphatically that in terms of international use the euro would achieve 'full parity' with the greenback in as little as five to 10 years. Alogoskoufis \& Portes (1997) thought that it might even happen 'immediately'. In fact, however, nothing like that has yet come to pass. It is perhaps not surprising, therefore, that as the years have gone by, enthusiasts have grown more hesitant to set a date for the euro's ascendance. The most notable exceptions are Menzie Chinn and Jeffrey Frankel, who in successive econometric studies have daringly suggested that Europe's currency might overtake the dollar by 2022 (Chinn \& Frankel, 2007) or possibly even as early as 2015 (Chinn \& Frankel, 2008). But even that is much farther off than many were forecasting back when the euro was born. Enthusiasts still firmly believe that the euro is the currency of the future. But, frustratingly, the future keeps receding.

Even now, in the midst of the greatest economic crisis since the 1930s, the dollar has retained its historical dominance. If ever there was an opportunity to tip preferences in favour of the euro, it should have been during the past two years, following the sub-prime mortgage collapse in the US. Very soon the soundness of America's entire financial structure was thrown into question. One after another, venerable banking institutions fell into insolvency, whole classes of 'toxic' securities become unsalable at any price, the Treasury and Federal Reserve were forced into ever-deeper interventions to keep the system afloat, and the broader American economy sank rapidly into recession. Yet even at moments of greatest panic, market actors looked to the greenback, not the euro, for safety. As the crisis intensified, spreading to the EU and elsewhere, the dollar actually rose sharply against Europe's money. Global demand for US Treasury bills was so great that 


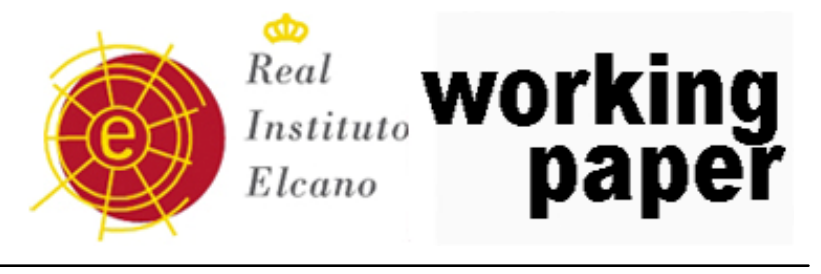

yields fell nearly to zero, while euro-denominated assets have been abandoned. The future of Europe's money, it seems, still lies out of reach.

\section{A Structural Disadvantage}

Will the future ever arrive? Of course it will, say the currency's fans. 'The euro has the capacity to catch up', firmly asserts one source (Walter \& Becker, 2008, p. 10). Declares another: 'To keep the euro down forever, you would need to rely on some rather farfetched conspiracy theories' (Münchau, 2008). Conspiracy theories, however, are hardly necessary to warrant a healthy dose of scepticism. A decade after the monetary union's birth, it is becoming increasingly clear that the obstacles to the euro's path are by no means trivial, as I have long argued (Cohen, 2003, 2008). In fact, there are serious deficiencies inherent in the institutional design of EMU that are bound to limit the currency's appeal (Cohen \& Subacchi, 2008). The euro's handicaps include troubling ambiguities in the EMU's governance structure -difficult to avoid when a single currency is jointly managed by more than one sovereign state- as well as a strong anti-growth bias built into the bloc's provisions for monetary and fiscal policy. As a rival to the dollar, Europe's money is at a distinct structural disadvantage. The greenback may have deficiencies of its own, but Europe has failed to provide an attractive alternative.

The core problem is that the euro area -also referred to as the euro zone or the eurosystem- is an artificial construct, lacking the clear lines of authority traditionally associated with the management of money by a single national government. Though the bloc does have a central monetary agency, the European Central Bank (ECB), there is neither a common regulatory regime nor a unified fiscal authority to provide overall direction. As Jean-Claude Trichet, the ECB's President, has lamented: 'We are not a political federation... We do not have a federal budget' (as quoted in the New York Times, $6 / \mathrm{X} / 2008$ ). Effectively the euro is a currency without a country, the product of an international treaty rather than the expression of one sovereign power. For actors outside the EMU, Europe's money can be considered only as good as the political agreement underlying it.

The dilemma has long been apparent (Cohen, 2008). The underlying political agreement might remain solid in 'normal' times. But would it hold up in the midst of a crisis? Under the Maastricht Treaty, the EMU's founding document, few specific tasks were assigned to the ECB to maintain financial stability. For most supervisory or regulatory powers the ruling principle was to be decentralisation, otherwise known as subsidiarity -the notion 
that the lowest level of government that can efficiently carry out a function should do so-. Formal authority for crisis management was to remain at the national level, just as it did before EMU. Watchful observers had repeatedly warned about the risks of such a fragmented governance structure, which left the EMU remarkably unprepared to cope with any major disruption. In the words of the International Monetary Fund (IMF, 2007, para. 12): 'The core problem is the tension between the impulse toward integration, on the one hand, and the preference for a decentralised approach, on the other... This setting rules out efficient and effective crisis management and resolution'. No one, it seemed, was directly accountable for the stability of the euro area as a whole.

Now, with the spread of the current crisis, the EMU's chickens have come home to roost. The necessary political agreement has proved lacking. While the US Treasury and Federal Reserve have been able to react to developments decisively and with alacrity (if not always with great efficacy), European governments remain divided and uncertain. The ECB has been active in injecting liquidity into the system -but under the Maastricht Treaty that is all it can do-. National policy makers, in the meantime, have clung to a piecemeal, patchwork approach -an 'every-country-for-itself' response that certainly has done little to bolster confidence in Europe's joint currency-. Even when an agreement was announced a year ago to recapitalise financial institutions and guarantee inter-bank lending, the details of implementation were left to individual governments. Policy makers resisted setting up a Europe-wide fund for fear that their own taxpayers might end up bailing out other countries' banks or depositors. Similarly, responsibility for fiscal stimulus has been left to the separate members, with predictably poor results. An emergency summit last March, called in the hope of crafting a joint European response to the crisis, ended in total disarray. The EU, said a prominent German journalist, had proved that it is 'just a fair-weather union' (as quoted in the New York Times, 2/III/2009). The absence of effective coordination no doubt helps explain why, despite America's considerable travails, global preferences have still failed to tip towards the euro. Market actors recognise that in the end, Europe's governments simply do not seem to trust each other enough to act decisively in their common interest. As the Wall Street Journal (7/X/2008) wryly commented: 'This is a poor record for the EU 51 years after its founding'.

To a large extent, the hopes of euro enthusiasts have always been a reflection of their ambitions for the broader EU project. The appeal of the currency would grow naturally with the construction of a united Europe. But market forces alone cannot guarantee success. Given the EMU's structural handicaps, it seems clear that a determined public effort will be required if the currency is ever to live up to its fans' aspirations. Promotion of the international role of the euro would have to be made an explicit goal of policy. Otherwise, Europe's money in a sense could turn out always to be the 'currency of the future', forever aspiring to catch up with the dollar but, like an asymptote, destined never to quite get there. 


\section{Vague Vision}

The vision of euro enthusiasts was always a bit vague. What does it mean to 'catch up with' or 'overtake' the dollar? At issue is the degree or extent of use of a money for various international purposes -what is commonly referred to as currency 'internationalisation'-. Cross-border usage of Europe's currency was expected to grow. Without further explanation, however, the notion of currency internationalisation is ambiguous at best. In practical terms, at least three separate dimensions are involved: trajectory, scope and domain. To assess the euro's achievements and prospects, all three dimensions must be considered.

By trajectory I mean the path traced by the euro as its use increases. Can the growth of usage be expected to continue ever upwards until parity with the dollar (or more) is attained, or is some ceiling likely to be hit short of that goal? By scope I mean the range of functional categories of use. Can euro usage be expected to grow for all international purposes, or just a select few? By domain I mean the geographic scale of use. Can euro usage be expected to expand across most parts of the globe, or in just a more limited number of countries or regions?

Euro enthusiasts anticipated that Europe's currency would do well in all three dimensions. Cross-border usage would not bump up against a low ceiling and would be extensive in terms of both function and geography. In short, the euro's reach would in time span the globe, fully matching if not surpassing the dollar in both scope and domain. Reality, however, has turned out to be much more mundane. The vision of the currency's fans has proved faulty.

For a broad picture of what is really happening, there is no more authoritative source than the Review of the International Role of the Euro published annually by the European Central Bank (ECB, 2008). Data are provided on all three dimensions involved. With respect to all three, the ECB's conclusions are unambiguous -and damning-. The euro's reach, it turns out, has greatly exceeded its grasp.

Concerning trajectory, the ECB observes that international use of the euro has decelerated noticeably and appears to have stabilised. A fast early start was certainly to be expected, once market actors were persuaded that the euro was here to stay. From the moment of its birth, Europe's new money clearly enjoyed many of the attributes necessary for competitive success. These included a large economic base in the membership of the euro zone, initially numbering some 11 countries -including some of the richest economies in the world- and now up to 16 partners. They also included unquestioned political stability and an enviably low rate of inflation, all backed by a joint monetary authority, the ECB, that was fully committed to preserving confidence in the currency's future value. Moreover, there was every reason to believe that sooner or later the global position of the dollar would weaken, owing to the America's persistent payments deficits and looming 
foreign debt. Hence it was no surprise that in the euro's early days, use seemed to be expanding exponentially. 'Momentum has led to an increase in the international role of the euro', proclaimed the ECB in 2002 (ECB, 2002, p. 11). But subsequently, it is plain that momentum has slowed considerably. After its fast start, the ECB now ruefully concedes, the international role of the euro 'has been broadly stable for around five years' (ECB, 2008, p. 11).

In effect, the euro has done little more than hold its own as compared with the past aggregate market shares of EMU's 'legacy' currencies. Given the fact that Germany's old Deutsche mark (DM) had already attained a number-two ranking in the monetary system, second to the greenback, anything less would have been a real shock. But beyond that, a ceiling does indeed appear to exist. Straight-line extrapolation of the euro's early acceleration far into the future does not seem warranted.

Likewise, with respect to scope, it is evident that growth of euro usage has been uneven across functional categories. The expansion of international use has been especially dramatic in the issuance of debt securities, reflecting the growing integration of the EMU's financial markets. There has also been some modest increase in the euro's share of trade invoicing and central-bank reserves. But in other categories, such as foreignexchange trading or banking, the dominance of the dollar remains as great as ever. The ECB's polite way of putting this is that use of the euro has been 'heterogeneous across market segments' (ECB, 2008, p. 7).

The picture is also clear with respect to domain, which is sharply bifurcated. For the most part, internationalisation of the euro has been confined to countries with close geographical and/or institutional links to the euro zone -what might be considered EMU's natural hinterland-. 'The euro's turf', the economist Charles Wyplosz (1999, p. 89) calls it. These countries include the newest members of the EU, all destined eventually to join the EMU, as well as other candidate states (eg, Croatia, Montenegro) and nonmember neighbours (Norway and Switzerland). They also include most of the nations around the Mediterranean littoral as well as a good portion of sub-Saharan Africa. In these countries, where trade and financial ties are deep, the euro obviously enjoys a special advantage. Elsewhere, in stark contrast, scale of use drops off abruptly, and Europe's currency remains very much in the greenback's shadow. Concludes the ECB (2008, p. 7): 'The Review confirms the largely regional character of the euro'.

\section{Discord?}

In sum, the conclusion seems undeniable. As an international currency, the euro's prospects are limited. There is no doubt of the money's dominance in its own neighbourhood; nor can one deny the considerable success it has attained in selected activities such as bond issuance. But overall, after a fast start, its trajectory has clearly bumped up against a ceiling, falling short of enthusiasts' aspirations. Left on its own, 
Europe's money appears destined to remain a distant second to the dollar far into the foreseeable future.

But what will happen if the EMU authorities choose not to leave the euro on its own? Officially, European aspirations remain modest. According to authoritative statements by the ECB, the euro's development as an international currency -to the extent it happenswill mainly be a market-driven process, simply one of many possible by-products of monetary unification. From the very beginning, the ECB has insisted that euro internationalisation 'is not a policy objective [and] will be neither fostered nor hindered by the Eurosystem... The Eurosystem therefore adopts a neutral stance' (ECB, 1999, p. 31 \& 45). Behind the scenes, however, there are known to be considerable differences of opinion, with the eventual direction of policy still unsettled. While many in Europe are indeed inclined to leave the future of the euro to the logic of market competition, many others -aware of the dollar's strong incumbency advantages- favour a more proactive stance to reinforce their currency's potential. The temptation is bound to be especially great so long as America's economy and financial markets remain weakened by today's ongoing crisis.

In short, the chance of a leadership struggle with the US cannot be ruled out. The risk of discord is real. The question is: should we be worried?

\section{Leadership Struggle}

Much depends on how aggressive policy makers on each side might choose to be in promoting their respective monies. As I have noted elsewhere (Cohen, 2004), a critical distinction must be drawn between two different kinds of leadership aspirations in monetary affairs: informal and formal. Much rides on the difference.

Informal leadership refers to dominance among market actors -the scope of a money's use for private market purposes-. At this level, a competitive struggle already exists. In the EMU, policy is already actively engaged in trying to improve the appeal of the euro, particularly via financial-market reform; in defensive reaction, the US will do what it can to sustain the attractiveness of the greenback. The consequences of an informal leadership struggle, however, are apt to be largely benign, since governments take this sort of contestation very much in their stride. Rivalry to promote or sustain each currency's competitiveness can be regarded as a natural feature of a decentralised monetary system based largely on market principles. The global community might even benefit if the result is lower transaction costs and more efficient capital markets.

But what if the players elect to go a step further, to seek to alter the behaviour of state actors -what I term formal leadership?-. The aim in this case is to alter currency choices at the level of public policy: to induce governments to switch to a different reserve currency or perhaps even to adopt the foreign currency domestically in place of their own national 
money. The result, ultimately, would be the formation of organised currency blocs, not unlike the old sterling area that coalesced around the UK's pound in the interwar period.

As in inter-state relations generally, tactics in a formal leadership struggle in monetary affairs may involve varieties of either coercion or persuasion, depending on the circumstances. Currencies might be directly imposed on client states in a manner similar to what Susan Strange (1971) meant by a 'Master Currency'. In the language of Jonathan Kirshner (1995), countries could be threatened with enforcement or expulsion if they do not align themselves monetarily -a threat of sanctions, say, or a withdrawal of past commercial or financial privileges-. Alternatively, attractive inducements of an economic or political nature might be offered to reshape policy preferences in manner analogous to Strange's notion of a 'Negotiated Currency' -what Kirshner (1995) describes as entrapment-.

Whatever the tactics used, the consequences for the global monetary system could be dangerous. In a formal leadership struggle, by definition, competition becomes more overtly politicised and hence less easy to contain. Economically, increasingly antagonistic relations could develop between mutually exclusive groupings, reversing decades of multilateral liberalisation in trade and financial markets. Politically, currency rivalry could become transformed into serious geopolitical conflict.

Many observers discount the probability of a formal leadership struggle, pointing to the evident perils involved. Any efforts to alter prevailing currency choices at the state level would imply a cutback of dollar accumulations, which in turn could lead to a sharp depreciation of the greenback, causing massive losses on existing reserve holdings. Would governments truly risk such self-inflicted wounds? To avert a doomsday scenario, it makes more sense for state actors to support the greenback -or, at least, not undermine it- whether they like it or not. Optimists see this as nothing more than enlightened selfinterest.

Others, however, see it as more like the notorious balance of terror that existed between the nuclear powers during the Cold War -a 'balance of financial terror', as the former Treasury Secretary Larry Summers (2004) has described it-. A fear of mutually assured destruction is surely a powerful deterrent to overtly destabilising behaviour. But fear cannot rule out the possibility of miscalculation or even mischief by critical players. In fact, the balance of financial terror is inherently unstable and could conceivably break down at any time.

\section{Breakdown?}

Will the balance break down? Prediction is hazardous, of course; a doomsday scenario can hardly be excluded. But I am less persuaded than some observers, such as Kirshner (2008), that the wolf is actually at the door, ready to wreak systemic havoc. Certainly the 
foundations for a confrontation over formal leadership are in place, suggesting that a threat somewhere, sometime, is possible. There seems little reason for concern in the Western Hemisphere, where a dollar bloc has effectively existed for some time; there, the greenback remains largely unchallenged. Conversely, few question the euro's increasing dominance in the EMU's near hinterland, including much of Africa. But elsewhere room does indeed exist for serious clashes. The greatest danger is to be found in the Middle East, where the greenback has long reigned supreme. Here, as I have previously suggested (Cohen 2006), Europe could understandably be tempted to seek a greater role for the euro.

With its concentration of wealthy oil exporters, the Middle East would seem a prize well worth fighting for. At the moment, America's dollar is not only the standard for invoicing and payments in world energy markets. It also accounts for the vast majority of central bank reserves and government-held investments in Middle Eastern countries and, except for Kuwait, is the sole anchor for their exchange rates. Yet overall, the region's commercial ties are far more oriented towards Europe -a disjunction that many Europeans find anomalous, even irrational-. Repeatedly, the question is asked: would it not make more sense for the area to do business with its largest trading partner, Europe, in Europe's own currency rather than the greenback? And if so, would it not then make sense to switch to the euro as an anchor and reserve currency as well? Europe is well placed to make the Middle East a currency battleground.

Certainly, the possibility of a switch to the euro is tempting from a European perspective. Displacement of the dollar might go far towards restoring a measure of Europe's historically privileged position in the region. Arguably, the prospect might be tempting for Middle Eastern governments too from a purely economic point of view. It is well known that from time to time oil-exporting states have explored alternatives to the dollar, only to be discouraged by the lack of a suitable substitute. Now, with the arrival of the euro, many see the possibility of a truly competitive rival to the greenback. Talk of a switch to the euro (or to a currency basket heavily weighted towards the euro) has been particularly intense in recent years as a result of the dollar's most recent bout of weakness.

Any effort to capitalise on the greenback's travails, however, would surely provoke determined resistance from the US, which has long linked the region's use of the dollar to broader security concerns. For Washington, there is no higher politics than the Great Game being played out today in the energy-rich Middle East. America needs both the region's oil and continued support for the greenback; the security assurances provided to local governments are the price paid for both. With so much at stake, the level of US tolerance for a formal currency challenge from Europe would be correspondingly low, making geopolitical conflict a virtual certainty. 
Indeed, for some observers, the conflict has already begun. Theories abound that America's 2003 attack on Iraq, following as it did shortly after Saddam Hussein's decision to demand payment in euros for Iraqi oil exports, was motivated above all by a desire to sustain the dollar's role in the region. Though the idea is wholly unsubstantiated by hard evidence, one need not be a sensationalist to recognise the seeds of truth that it contains. A battle of currencies in the Middle East could get nasty.

Would Europe risk it? In the end, however strongly tempted, the Europeans are more likely to keep their aspirations in check, averting direct confrontation with Washington. Even after the Bush Administration's decision to promote 'regime change' in Iraq, there is no consensus among Europeans to risk the broader political and security relationship that they have long enjoyed with the US. Beyond their currency's natural home in Europe's immediate neighbourhood, therefore, they will most probably act with restraint. Manoeuvring for advantage in the Middle Eastern region will undoubtedly persist, but the euro's challenge to the dollar is unlikely to be allowed to get out control.

\section{Conclusion}

The bottom line, therefore, is clear. Despite the aspirations of euro enthusiasts, the dollar has not in fact met its match. The greenback's margin of dominance may have narrowed somewhat, but not even the stubborn crisis in the US financial markets has served to tip market preferences. Whether the new Administration of President Barack Obama can succeed in restoring the vitality of America's economy remains an open question. But with its vigorous policy initiatives Washington has at least succeeded in stemming past erosion of confidence in US financial leadership. The euro, meanwhile, remains at a distinct structural disadvantage, with little natural appeal beyond the European hinterland. In the absence of a determined effort to overcome the obstacles to the euro's path, Europe's money seems destined to dominate nowhere beyond its own backyard.

Can Europe's leaders undertake the reforms needed to improve the EMU's governance structure? Can they frame the policies needed to promote the euro's role without provoking a serious conflict with the US? The global economic crisis that erupted two years ago offered a golden opportunity for Europe to wrest financial leadership from the US, either on its own or in coordination with Japan, China and others. To date, however, European governments have not proved equal to the challenge, seemingly unable to coordinate initiatives even within their own institutions. The EU remains a 'fair-weather union', hampering euro aspirations.

Both data and political analysis, therefore, point to the same conclusion. Europe's money is unlikely to catch up with, let alone overtake, the dollar. America's greenback, long preeminent in monetary affairs, will remain the only truly global currency. 


\section{References}

Alogoskoufis, George, \& Richard Portes (1997), 'The Euro, the Dollar, and the International Monetary System', in Paul R. Masson, Thomas H. Krueger \& Bart G. Turtelboom (Eds.), EMU and the International Monetary System, International Monetary Fund, Washington DC, ch. 3.

Bergsten, C. Fred (1997), 'The Impact of the Euro on Exchange Rates and International Policy Cooperation', in Paul R. Masson, Thomas H. Krueger \& Bart G. Turtelboom (Eds.), EMU and the International Monetary System, International Monetary Fund, Washington DC, ch. 2.

Chinn, Menzie, \& Jeffrey Frankel (2007), ‘Will the Euro Eventually Surpass the Dollar as Leading International Reserve Currency?', in Richard H. Clarida (Ed.), G7 Current Account Imbalances: Sustainability and Adjustment, University of Chicago Press, Chicago, IL, ch. 8.

Chinn, Menzie, \& Jeffrey Frankel (2008), 'Why the Euro Will Rival the Dollar', International Finance, nr 11:1, Spring, p. 49-73.

Cohen, Benjamin J. (2003), 'Global Currency Rivalry: Can the Euro Ever Challenge the Dollar?', Journal of Common Market Studies, 41:4, September, p. 575-595.

Cohen, Benjamin J. (2004), The Future of Money, Princeton University Press, Princeton, NJ.

Cohen, Benjamin J. (2006), 'The Euro and Transatlantic Relations', in Thomas L. Ilgen (Ed.), Hard Power, Soft Power and the Future of Transatlantic Relations, Ashgate, Burlington, VT, p. 73-89.

Cohen, Benjamin J. (2008), 'The Euro in a Global Context: Challenges and Capacities', in Kenneth Dyson (Ed.), The Euro at Ten: Europeanization, Power, and Convergence, Oxford University Press, Oxford, ch. 2.

Cohen, Benjamin J., \& Paola Subacchi (2008), 'A One-and-a-Half Currency System', Journal of International Affairs, nr 62:1, Fall/Winter.

European Central Bank (1999), 'The International Role of the Euro', ECB Monthly Bulletin, August, p. 31-53.

European Central Bank (2002), Review of the International Role of the Euro, Frankfurt, December.

European Central Bank (2008), Review of the International Role of the Euro, Frankfurt, July.

International Monetary Fund (2007), Concluding Statement of the IMF Mission on Euro-Area Policies, Washington DC, 30/V/2007.

Kirshner, Jonathan (1995), Currency and Coercion: The Political Economy of International Monetary Power, Princeton University Press, Princeton, NJ.

Kirshner, Jonathan (2008), 'Dollar Primacy and American Power: What's At Stake?', Review of International Political Economy, nr 15:3, August, p. 418-438.

Münchau, Wolfgang (2008), 'This Crisis Could Bring the Euro Centre-Stage', Financial Times, 23/III/2008.

Strange, Susan (1971), Sterling and British Policy: A Political Study of an International Currency in Decline, Oxford University Press, London. 
Summers, Lawrence H. (2004), The U.S. Current Account Deficit and the Global Economy, Per Jacobsson Foundation, Washington.

Walter, Norbert, \& Werner Becker (2008), 'The Euro Hits the Big Time', EU Monitor, nr 58, Deutsche Bank, Frankfurt, June.

Wyplosz, Charles (1999), 'An International Role for the Euro?', in Jean Dermine \& Pierre Hilton (Eds.), European Capital Markets with a Single Currency, Oxford University Press, New York, p. 76-104. 